\title{
Hernia inguinal con deslizamiento vesical
}

\author{
Capdevila Querol S, Umbert Canals B, Vargas Blasco C. \\ Servicio de Urología. Hospital de Viladecans. Barcelona.
}

\begin{abstract}
Presentamos el caso de un paciente varón de 81 años sin alergias conocidas, con antecedentes de fibrilación auricular, EPOC y HBP (RTU previa hace 8 años).

Presenta hernia inguinoescrotal derecha de gran volumen y larga evolución.

Ante la sospecha ecográfica de herniación vesical se procedió a estudio pielográfico confirmándose la presencia de contenido vesical en dicha hernia.
\end{abstract}

Dr. S. Capdevila Querol

E-mail: scq33020@hotmail.com

(Trabajo recibido el 13 de septiembre 2005)
Actas Urol Esp. 2006;30(7):732

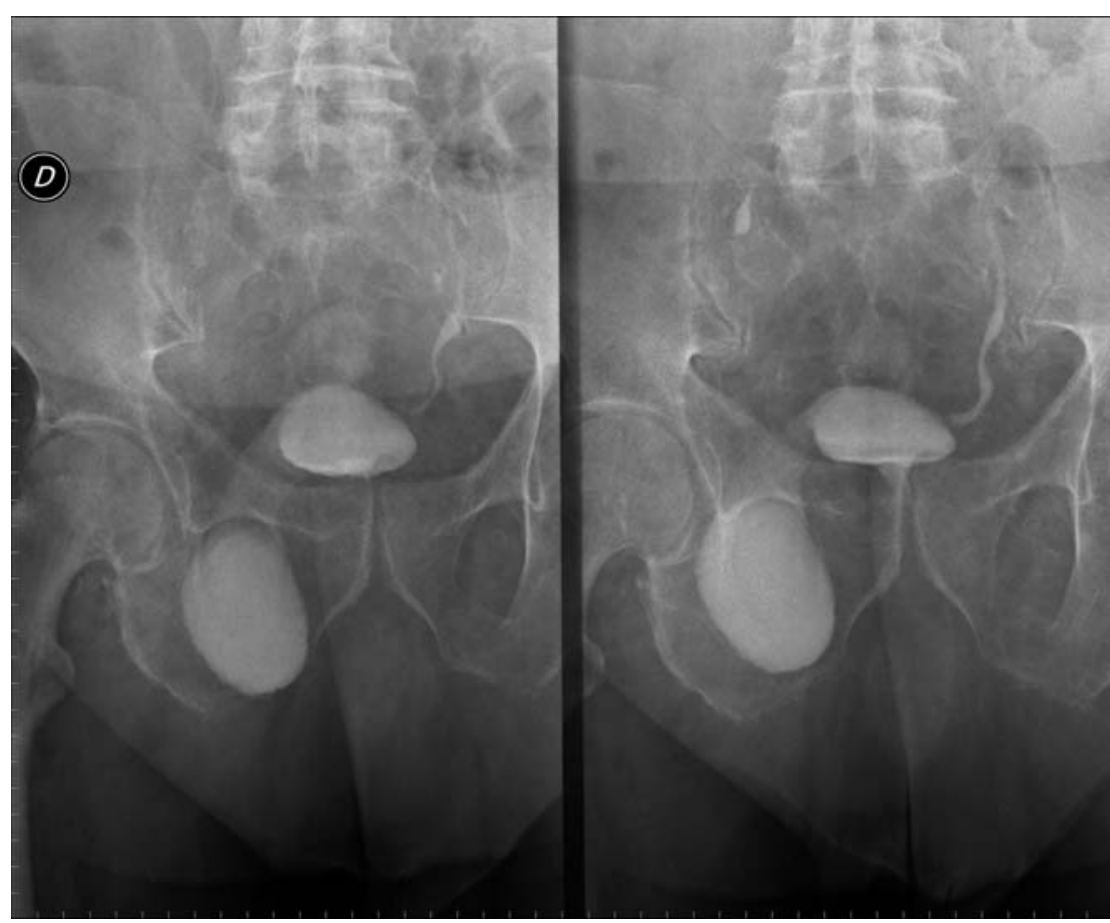

FIGURA 1 